\title{
Impact of water stress on radiation interception and radiation use efficiency of Soybeans (Glycine max L. Merr.) in Nigeria
}

\author{
Omotayo B. Adeboye ${ }^{1 *}$, Bart Schultz ${ }^{2}$, Kenneth O. Adekalu and Krishna Prasad ${ }^{3}$
}

\author{
*Correspondence: \\ adeboyeomotayo@yahoo. \\ com \\ ${ }^{1}$ Department of Agricultural \\ and Environmental \\ Engineering, Obafemi \\ Awolowo University, lle-lfe, \\ Nigeria \\ Full list of author information \\ is available at the end of the \\ article
}

\begin{abstract}
Soybean is the world's major oilseed crop. Field experiments were conducted for 2 years on soybeans in order to study the effects of deficit irrigation (DI) during reproductive stages on radiation interception, radiation use efficiency (RUE), seed yields, harvest index $(\mathrm{HI})$ and crop water productivity (WP). The water regimes were full irrigation (FI), Dl every other week during flowering, pod initiation, seed filling and commencement of maturity. Average seasonal extinction coefficient $(\lambda)$ ranged from 0.45 for DI during commencement of maturity to 0.47 for the other deficit methods. Pooled over the seasons and across water regimes, the fraction of incident photosynthetically active radiation was strongly correlated with the leaf area index (LAI). The aerial dry matter was strongly correlated with daily photosynthetically active radiation (PAR) for all water regimes. Across the water regimes, average seasonal RUE ranged from $1.07 \mathrm{~g} \mathrm{MJ}^{-1}$ incident photosynthetically active radiation (IPAR) for FI to $1.19 \mathrm{~g} \mathrm{MJ}^{-1}$ IPAR for DI during pod initiation. Reduction in the seasonal RUE ranged from 3.8 to $19.7 \%$ for DI, while for the yield it ranged from 15.6 to $45.8 \%$. Seed yield was positively and significantly correlated ( $p<0.0001$ ) with RUE, cumulative intercepted PAR and HI across water regimes. WP is positively related with seed yield $\left(r^{2}=0.98 ; p<0.0001\right)$, total intercepted PAR $\left(r^{2}=0.99 ; p<0.0001\right)$ and RUE $\left(r^{2}=0.54 ; p=0.02\right)$. DI reduced $\mathrm{LAl}$, cumulative incident photosynthetically active radiation (TIPAR) and seed yield. DI during pod initiation and seed filling reduced substantially the seasonal RUE and seed yield than other reproductive stages. In conclusion water stress did not have significant impacts on $\lambda$ and RUE during every reproductive stage for soybeans (TGX $14482^{\mathrm{E}}$ ).
\end{abstract}

Keywords: Soybean, Irrigation, Deficit irrigation, Radiation use efficiency, Yield, Water productivity, Nigeria

\section{Background}

Under field conditions, the development of crops depends on capacity of the canopy to intercept incident radiation and convert it into new biomass (Gifford et al. 1984). The amount of incident radiation intercepted depends on the leaf area index (LAI) and canopy orientation in space. The fraction of the incident photosynthetically active radiation (IPAR) that is absorbed by a canopy depends on the LAI and the arrangement of the leaves of the crop (Plenet et al. 2000). When there is no environmentally induced stress from water or air temperature, inadequate nutrition, pests and diseases the quantity 
of biomass produced by a growing crop is correlated to the amount of solar radiation (SR) or photosynthetically active radiation (PAR) intercepted by the green leaf area (LA) of a crop during its growth cycle (Monteith 1977). The slope of the linear relationship between biomass and total intercepted PAR or absorbed SR is taken as radiation use efficiency (RUE) of a crop (Monteith 1977; Ceotto and Castelli 2002). Simple models, which are used to simulate the growth of crops are derived from this linear relationship. For instance, seed yield is expressed as a function of the fraction of incident photosynthetically active radiation (fIPAR), harvest index (HI) and RUE (Monteith 1977; Turner et al. 2001; Saha et al. 2012).

There is variability in the fraction of intercepted radiation by plants along the growth cycle (Sivakumar and Virmani 1984) that depends largely on the green LA and extinction coefficient $(\lambda)$, which is a measure of the light profile in a canopy (Campbell and Norman 1998). It has been reported that $\lambda$ s of leguminous crops vary and are influenced by environmental and genetic factors. Environmental conditions such as air temperature and water stress modify leaf angle of inclination, spatial distributions (plant spacing and density) and optical properties which may occur from differences in content of Nitrogen (Jeuffroy and Ney 1997).

RUE is a basic parameter used in analyzing crop growth based on resource capture and use efficiency (Stockle and Kemanian 2009). It is used to evaluate the relative performance of crops under different locations and management practices (Monteith 1977; Sinclair and Muchow 1999). Reduction in RUE has commonly been observed during pod-filling in all species (Muchow 1985). In addition to the reduction of RUE, water stress also affects foliage expansion and eventually radiation capture (Jamieson et al. 1995; Stone et al. 2001; Inman-Bamber 2004). Reduction in RUE due to water stress was recorded for grain legumes for instance soybeans (Muchow 1985); Faba bean (Green et al. 1985), chickpea (Singh and Sri Rama 1989), sorghum (Rinaldi and Garofalo 2011) and winter wheat (Li et al. 2008). Data on productivity and resource use efficiency of soybeans during dry seasons are very scarce. Therefore, it is necessary to conduct research and find out whether the reduction in the $\lambda$ and RUE of soybean is due to genetic characteristics or water stress under drip irrigation conditions.

Soybean (Glycine $\max$ L. Merr.) is cultivated in almost all areas of Nigeria with low agricultural inputs during rainy seasons. The production of the crop in Nigeria has expanded because of its economic importance. The expansion of the poultry sector in the recent years has also increased demand for soybean meals in Nigeria. However, it is occasionally planted during the dry seasons because of high cost of irrigation facilities and possibility of low productivity. With the trend of fluctuations in rainfall over the years, potential farmers may shift the cultivation to dry seasons under drip or sprinkler irrigation systems. As the farmers are getting more awareness about the crop, the production of the crop will increase in the nearest future and this will necessitate cultivation during dry seasons.

Therefore, this research was carried out in order to study the effects of water stress using drip irrigation during the reproductive stages on the development of canopy in terms of LAI and fIPAR, total incident photosynthetically active radiation (IPAR) and model the relationship between intercepted PAR and RUE, LAI and seed yield of soybeans in Ile-Ife, Nigeria. 


\section{Materials and experimental methods}

\section{Study area}

The experiment was conducted at the Teaching and Research Farms of Obafemi Awolowo University, Ile-Ife, Nigeria located at latitude $7^{\circ} 28^{\prime} 0^{\prime \prime} \mathrm{N}$ and longitude $4^{\circ} 34^{\prime} 0^{\prime \prime} \mathrm{E}$, $271 \mathrm{~m}$ above the mean sea level during dry seasons of 2013 and 2013/2014. At intervals of $10 \mathrm{~min}$, air temperature and relative humidity were logged using VISALA HMP45 while wind speed was measured using ultrasonic anemometer (Campbell Scientific, USA) located at $300 \mathrm{~m}$ away from the experimental field. Global radiation was measured using pyranometers (Apogee Instruments, USA). The average seasonal maximum and minimum air temperature, relative humidity and mean global SR for the 2013 and 2013/2014 irrigation seasons are shown in Table 1. The first season was warmer than the second season. The seasonal effective rainfall in these irrigation seasons was 261 and $50 \mathrm{~mm}$, and the average seasonal reference evapotranspiration was 4.92 and $3.1 \mathrm{~mm} \mathrm{day}^{-1}$.

\section{Experimental design}

The treatments were:

- $T T_{1111}$ Irrigation was maintained weekly without stopping at any of the reproductive growth stage: flowering (R1 and R2 growth stages), pod initiation (R3 and R4 growth stages), seed filling (R5 and R6 growth stages) and maturity stage (R7 and R8 stages) (FI treatment);

- $T T_{0111}$ Irrigation was skipped every other week during flowering;

- $T T_{1011}$ Irrigation was skipped every other week during pod initiation;

- $T T_{1101}$ Irrigation was skipped every other week during seed filling;

- $T T_{1110}$ Irrigation was skipped every other week during maturity.

The treatments were laid out in a randomized complete block design with triplicates.

\section{Field layout, cultivation and measurement in the dry seasons}

The experimental field was harrowed at the commencement of the fieldwork in both seasons and the stumps were removed manually. Stubborn, annual and perennial

Table 1 Meteorological data measured near experimental fields in the irrigation seasons

\begin{tabular}{|c|c|c|c|c|c|c|c|c|c|}
\hline \multirow[t]{2}{*}{ Year/month } & \multicolumn{3}{|c|}{ Temperature $\left({ }^{\circ} \mathrm{C}\right)$} & \multicolumn{3}{|c|}{ Relative humidity (\%) } & \multicolumn{2}{|c|}{$\begin{array}{l}\text { Global solar radia- } \\
\text { tion }\left(\mathrm{W} \mathrm{m}^{-2}\right)\end{array}$} & \multirow{2}{*}{$\begin{array}{l}\text { Rainfall (mm) } \\
\text { Total } \pm \text { SD }\end{array}$} \\
\hline & Max & Min & Mean \pm SD & Max & Min & Mean \pm SD & Max & Mean \pm SD & \\
\hline \multicolumn{10}{|l|}{2013} \\
\hline Feb & 41.0 & 18.0 & $27.5 \pm 3.7$ & 94.3 & 10.1 & $66.0 \pm 18.6$ & 904 & $161 \pm 234$ & $55.3 \pm 2.0$ \\
\hline Mar & 34.5 & 21.3 & $27.2 \pm 3.4$ & 94.4 & 42.4 & $76.4 \pm 14.0$ & 810 & $128 \pm 219$ & $32.3 \pm 1.1$ \\
\hline Apr & 34.8 & 21.7 & $25.8 \pm 3.7$ & 94.5 & 40.4 & $78.5 \pm 13.7$ & 1003 & $190 \pm 266$ & $44.9 \pm 1.5$ \\
\hline May & 37.0 & 20.8 & $26.1 \pm 2.7$ & 95.6 & 15.6 & $81.5 \pm 12.9$ & 985 & $181 \pm 245$ & $129 \pm 4.2$ \\
\hline \multicolumn{10}{|l|}{$2013 / 2014$} \\
\hline Nov & 33.5 & 20.5 & $26.3 \pm 2.8$ & 100 & 37.9 & $87.2 \pm 22.3$ & 959 & $180 \pm 265$ & - \\
\hline Dec & 33.1 & 16.7 & $25.9 \pm 3.3$ & 100 & 20.3 & $78.6 \pm 23.5$ & 837 & $179 \pm 250$ & $50 \pm 1.7$ \\
\hline Jan & 35.4 & 18.1 & $26.4 \pm 3.2$ & 100 & 15.1 & $81.3 \pm 25.2$ & 841 & $152 \pm 219$ & - \\
\hline Feb & 36.3 & 19.7 & $27.5 \pm 3.7$ & 100 & 13.5 & $68.8 \pm 25.4$ & 798 & $166 \pm 229$ & - \\
\hline
\end{tabular}

The minimum global solar radiation in each day was zero. It was not written to avoid repetition 
grasses and spear grass were controlled by applying Force upTM, Isopropylamine salt at $3 \mathrm{~L} \mathrm{ha}^{-1}$. Pre-wetting was done to a depth of $20 \mathrm{~mm}$ in order to soften the soil and initiate germination of the seed. An indeterminate variety "TGX $14482^{\mathrm{E}}$, was planted on the 2nd February (DOY 33) (day of the year) in 2013 (first season) and 8th November 2013 (DOY 312), second season. The year 2012 was a wet year in the study area and much rainfall was recorded at the end of the year and early parts of 2013. In the first season, delay in the procurement of irrigation equipment coupled with logistic challenges was also responsible for the commencement of the experiment in the stated time. Three seeds were sown $4 \mathrm{~cm}$ below the soil surface. The plant spacing was 0.6 by $0.3 \mathrm{~m}$, which produced 55,556 plants ha ${ }^{-1}$. Each plot occupied $12 \mathrm{~m}^{2}$. An alleyway of $1 \mathrm{~m}$ was used in separating the plots from one another to allow for easy movement. The area of the experimental field was 19 by $15 \mathrm{~m}\left(285 \mathrm{~m}^{2}\right)$. After planting, soil insects, defoliating beetles and aphids were observed in the field and controlled by using Magic Force ${ }^{\mathrm{TM}}$ (Lambda-Cyhalothrin $15 \mathrm{~g} \mathrm{~L}^{-1}+$ Dimethoate $300 \mathrm{~g} \mathrm{LEC}^{-1}$ ), Jubaili Agro Chemicals, Jericho, Ibadan Nigeria at $1.5 \mathrm{~L} \mathrm{ha}^{-1}$ at intervals of 2 weeks. After physiological maturity of the crop on 25th May, 2013 (DOY 145) in 112 DAP (days after planting) and 25th February, 2014 (DOY 56), 110 DAP an area of $5.37 \mathrm{~m}^{2}$ (central rows) was harvested from each plot and the seed yields per ha were estimated. HI was determined using the Eq. 1:

$$
H I=\frac{Y}{D A B}
$$

where, $Y=$ seed yield $\left(\mathrm{t} \mathrm{ha}^{-1}\right), D A B=$ dry aboveground biomass $\left(\mathrm{t} \mathrm{ha}^{-1}\right)$.

\section{Water application and design of drip irrigation system}

The daily crop water use was estimated using the Penman-Monteith approach described in Allen et al. (1998). The length of each stage was taken from the records taken during experiments conducted on soybean in the rainy seasons of 2011 and 2012 in the same area. The estimated peak evapotranspiration during the initial, and development stages was 1.13 and $6.53 \mathrm{~mm} \mathrm{day}^{-1}$ respectively while at mid and late stages, it was 6.69 and $3.83 \mathrm{~mm} \mathrm{day}^{-1}$ respectively. A pressure compensating inline-drip line (Dripworks, Inc., $190 \mathrm{CA}$, USA) whose capacity was $2.21 \mathrm{~h}^{-1}$, pressure of 1 bar was used to apply water to the crop during the growing seasons. The length of each lateral was $5 \mathrm{~m}$ and contained 17 point in-line emitters, which were pre-spaced at intervals of $0.3 \mathrm{~m}$. The pressure compensating mechanism ensures even distribution of pressure along the laterals even in hilly and undulating areas (Michael 2008). At the commencement of the experiments, the coefficient of variation of the discharges from the emitters was 0.03 which was described as excellent for a point source emitter (Michael 2008). The statistical uniformity indicator $\mathrm{U}_{s}$, a measure of the uniformity achieved by each emitters was $95 \%$. The emission uniformity of the drip system was $90.7 \%$ according to the equation in Keller and Bliesner (1990). Volume of water required per plant per day at the initial stage was determined from the ratio of the product of peak evapotranspiration $\left(1.13 \mathrm{~mm} \mathrm{day}^{-1}\right)$ and wetted area of each plant to the emission uniformity. The initial stage was expected to last for 25 days under the conditions in Ile-Ife and the estimated total volume of water to be supplied per plant was $1.50 \mathrm{~L}$. The estimated field water requirement at initial stage was $1530 \mathrm{~L}$. The daily water requirements during the mid (40 days) and late (18 days) 
seasons were 6.69 and $3.83 \mathrm{~mm} \mathrm{day}^{-1}$ respectively. Using the same procedure, the estimated daily water needs per plant during these stages were 0.36 and $0.21 \mathrm{~L}$ respectively. Similarly, the amount of water budgeted for the entire experimental fields during these periods were 14,700 and $3860 \mathrm{~L}$ respectively. At the initial stage, the readily accessible soil moisture was $5.5 \mathrm{~mm}$. Irrigation frequency was determined from the ratio of the readily available moisture to the peak water use of $1.13 \mathrm{~mm} \mathrm{day}^{-1}$ and this gave an average of 5 days. From the calibrated flow rate of the emitter and wetted area of the plant, adding $5.5 \mathrm{~mm}$ of water per irrigation would take $0.2 \mathrm{~h}$. Details can be found in Adeboye et al. (2015).

\section{Measurement of soil moisture}

During the irrigation seasons, soil samples were collected from replicates in each treatment at intervals of $10 \mathrm{~cm}$ from 0 to $60 \mathrm{~cm}$-surface and the moisture content was determined using the gravimetric method. Wet soil samples were collected using a $53 \mathrm{~mm}$ diameter steel core sampler at 7:00 a.m. during each measurement (Ali 2010). The samples were weighed immediately in the field, kept in sealed polythene bags before transport to the laboratory. The samples were oven-dried at $105{ }^{\circ} \mathrm{C}$ for about $48 \mathrm{~h}$ until the weight was constant. Measurement of the soil moisture content was done prior to irrigation in order to determine the root zone depletion and net water requirements. The volumetric water content was determined by multiplying soil moisture measurement (\%) by bulk density of each layer. The volumetric soil moisture was converted to linear depth $(\mathrm{mm})$ of water by multiplying it with the depth of each layer. There was rainfall in a few days during the fieldwork and this was built into the irrigation schedule by adding the effective rainfall to the plant available water and computing the number of days it would take the plant to use it.

For each treatment, irrigation water was applied equally (same amount and frequency) until the commencement of flowering when skipping of irrigation began in the selected treatments. Irrigation was done when $50 \%$ of the total available water had been depleted. The soil within the root zone was filled up to field capacity during irrigation. The total available water was $110 \mathrm{~mm} \mathrm{~m}^{-1}$. The irrigation requirement of the crop was determined using Eq. 2 (Ali 2010):

$$
d=R-\sum_{i=1}^{n} \frac{\left(M_{f c i}-M_{b i}\right)}{100} \times A_{i} \times D_{i}
$$

where, $d=$ net amount of irrigation applied $(\mathrm{mm}), \mathrm{R}=$ rainfall $(\mathrm{mm}), M_{f c i}=$ field capacity in the ith soil layer $\left(\mathrm{m}^{3} \mathrm{~m}^{-3}\right), M_{b i}=$ moisture content prior to irrigation in the ith soil layer $\left(\mathrm{m}^{3} \mathrm{~m}^{-3}\right), A_{i}=$ bulk density soil in the ith soil layer $\left(\mathrm{g} \mathrm{cm}^{-3}\right), D_{i}=$ soil depth within the root zone $(\mathrm{mm}), \mathrm{n}=$ number of soil layers within the root zone.

Irrigation frequency at each stage was determined from the ratio of the net water requirement to the peak water use $\left(\mathrm{mm} \mathrm{day}^{-1}\right)$. The area irrigated by each dripper was determined from the ratio of the product of plant spacing and percentage of the cropped area irrigated to the number of the drippers at each emission. Only $30 \%$ of the cropped area was irrigated. 


\section{Measurement of LAI and fIPAR}

At average intervals of 7 days from 14 DAP in both irrigation seasons, the green LAI, above and below PARs were measured at 400-700 nm using AccuPAR LP 80 (Decagon Devices, Inc., WA, USA) until maturity of the seeds. Measurements were extended to the maturity stage where green leaves were present. Ten samples of the below and above PARs were taken from triplicates of each treatment by placing the probe (line sensor) perpendicularly to the rows above and below the plant canopy. Total of 14 consecutive measurements of LAIs were made in both irrigation seasons. The fIPAR $\left(\mathrm{F}_{i}\right)$ was determined using the ratio of the $\mathrm{PAR}_{\text {below }}$ to the $\mathrm{PAR}_{\text {above }}$ as:

$$
F_{i}=1-\left(P A R_{\text {below }} / P A R_{\text {above }}\right)
$$

Average seasonal $\lambda$ was determined from the LAI and their corresponding fIPAR with intercept set at zero because LAI $=0$ when $\mathrm{PAR}_{\text {above }}=\mathrm{PAR}_{\text {below }}$ (Tesfaye et al. 2006; Farahani et al. 2009) using the equation:

$$
\lambda=-\ln \left(1-F_{i}\right) / L A I
$$

The slope of each regression line was taken as the seasonal $\lambda$ for each treatment (least square regression). The daily LAI for each treatment was determined by interpolation of the measured values. Using the daily LAI and the mean seasonal $\lambda$, the actual fIPAR was computed using Eq. 5 (Ritchie et al. 1985; Farahani et al. 2009; Narayanan et al. 2013):

$$
f I P A R=1-\exp (-\lambda \times L A I)
$$

\section{Dry above ground biomass (DAB)}

At intervals of 7 days from 14 DAP in both irrigation seasons, the above ground biomass was taken from an area of $0.179 \mathrm{~m}^{2}$ at random from the plot and replicates of each treatment and edge effects were avoided. The harvested biomass was oven dried at $70{ }^{\circ} \mathrm{C}$ for $24 \mathrm{~h}$ until constant weight (Farahani et al. 2009; Li et al. 2011). The DAB per unit area in each treatment was estimated. Total of 14 consecutive weekly measurements of the DAB were made in both irrigation seasons.

\section{Determination of RUE}

The relationship between PAR and SR was determined after continuous measurement of SR and PAR. Daily IPAR (MJ m ${ }^{-2}$ day $^{-1}$ ) from SR was determined using the Eq. 6 (Campbell and Norman 1998; Narayanan et al. 2013):

$$
I P A R=f_{e} \times S R[(1-\exp (-\lambda L A I]
$$

where, $f_{e}=$ proportion of PAR in SR (0.41).

Cumulative incident photosynthetically active radiation (TIPAR) was determined by summing the daily IPARs. RUE was determined by fitting a linear curve to the cumulative DAB and TIPAR the days the measurements of the DAB and PAR were made (Purcell et al. 2002; Tesfaye et al. 2006; Narayanan et al. 2013; Ceotto et al. 2013). The slope of the regression line was taken as the RUE. 


\section{Crop water use and water productivity}

The actual crop evapotranspiration was estimated using the soil water balance approach (Ali 2010). Moisture content was measured before irrigation in order to refill the soil at the root zone to field capacity. Runoff was measured by placing metallic boxes around plants within an area of $0.716 \mathrm{~m}^{2}$ in replicates of each treatment. The runoff within the area was directed towards a graduated plastic and measured after each rainfall event. Daily effective rainfall was determined from the difference between daily rainfall and runoff (Ali 2010). The contribution of the groundwater was ignored because the groundwater table was deeper than $10 \mathrm{~m}$. The drainage below the root zone was not detected during the cropping seasons and therefore considered negligible under drip irrigation as reported in Lovelli et al. (2007). The change in the moisture in the root zone was determined from measurement of soil moisture at the beginning and end of each stage of growth. Therefore, the seasonal crop water use was determined using Eq. 7 (Zhang et al. 2007):

$$
E T_{c}=I+R \pm \Delta S
$$

where, $\mathrm{ET}_{\mathrm{c}}=$ seasonal crop water use $(\mathrm{mm}), \mathrm{I}=$ irrigation $(\mathrm{mm}), \mathrm{R}=$ rainfall $(\mathrm{mm}), \pm \Delta \mathrm{s}=$ change in the soil moisture $(\mathrm{mm})$.

Crop water uses at different stages were aggregated to obtain seasonal water use. Crop water productivity (WP) was determined using (Zhang and Owie 1999):

$$
W P=\frac{Y}{E T_{c}}
$$

where, WP $=$ crop water productivity $\left(\mathrm{kg} \mathrm{ha}^{-1} \mathrm{~mm}^{-1}\right), \mathrm{Y}=$ marketable crop yield $\left(\mathrm{kg} \mathrm{ha}^{-1}\right), \mathrm{ET}_{\mathrm{c}}=$ as previously defined $(\mathrm{mm})$.

Similarly, irrigation water productivity (IWP) $\left(\mathrm{kg} \mathrm{ha}^{-1} \mathrm{~mm}^{-1}\right)$ was determined using Eq. 9:

$$
I W P=\frac{Y}{I}
$$

where, $\mathrm{Y}=$ as defined previously, $\mathrm{I}=$ seasonal irrigation water applied $(\mathrm{mm})$.

\section{Statistical analysis}

The analyses of variance (ANOVA) and SAS programmes were used for the statistical analysis of the mean of LAI, DAB, seed yield and HIs of the treatments. ANOVA permits the testing of the significant difference between averages of more than two samples. In situations where the F-test showed significant differences among treatment means, the differences among treatments were compared using Duncan's Multiple Range Test at $5 \%$ significance level.

\section{Results}

\section{LAI and fIPAR}

The development of LAI in the two seasons was similar (Fig. 1). The first season had a higher peak LAI than the second season. The development of the LAIs during preanthesis was similar in all the treatments until the skipping of irrigation every other week 

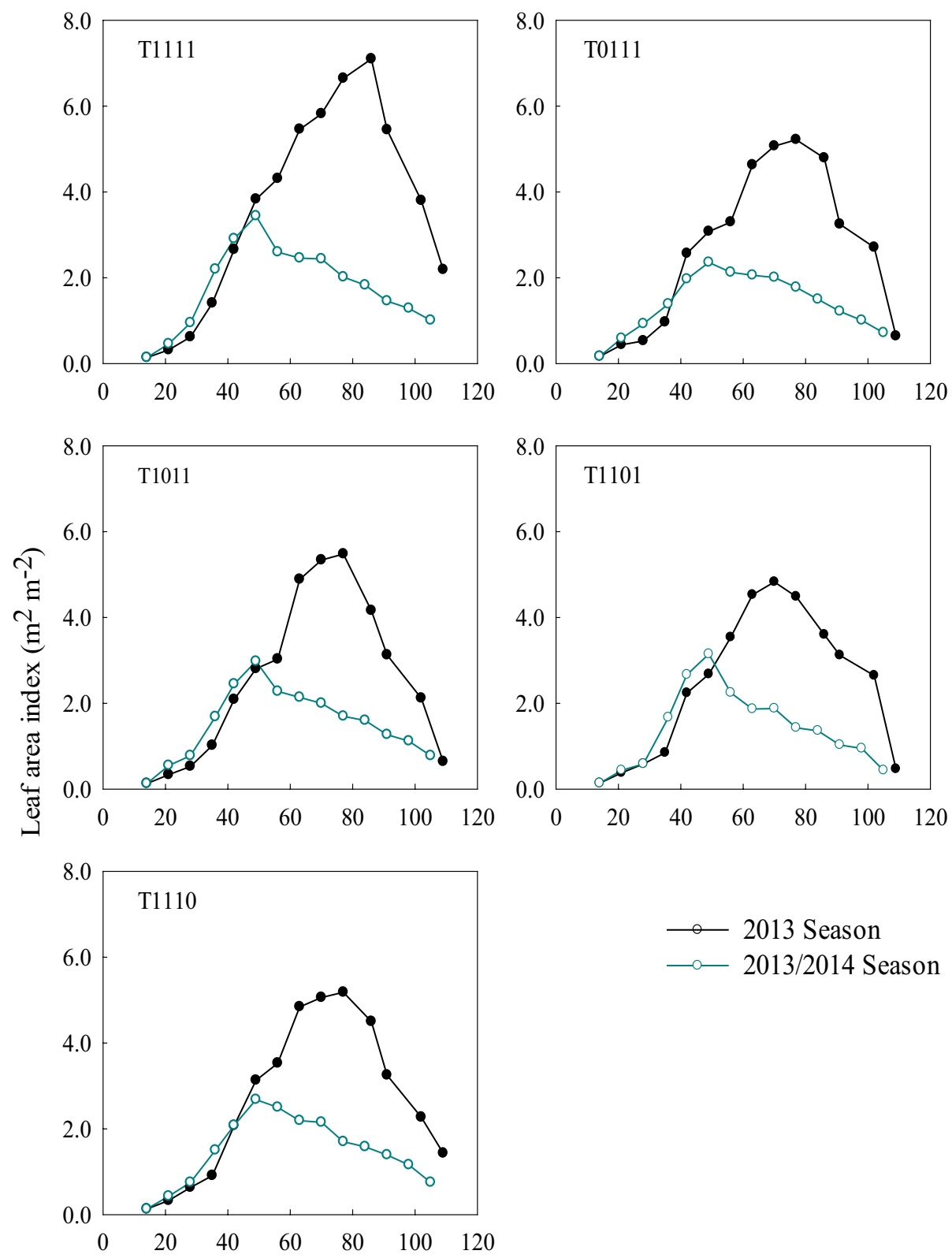

Day after planting

Fig. 1 Seasonal changes in LAls under full and deficit irrigation in soybeans in both seasons

during flowering. The fully irrigated treatment had the maximum LAIs of $7.10 \mathrm{~m}^{2} \mathrm{~m}^{-2}$ at 86 DAP in 2013 and was higher than the peak LAI when irrigation was skipped during flowering, maturity, pod initiation and seed filling by 33, 37 and $41 \%$ respectively. In the 2013/2014 irrigation season, the peak LAI was $3.44 \mathrm{~m}^{2} \mathrm{~m}^{-2}$ at 49 DAP and was higher than the corresponding LAI when irrigation was skipped during seed filling, pod initiation, maturity and flowering by $8,13,22$ and $31 \%$ respectively (Table 2). Significant reduction in the LAIs in the second season even in the fully irrigated treatment was due to environmental conditions. The peak LAI attained by the crop when irrigation was skipped during seed filling was $4.83 \mathrm{~m}^{2} \mathrm{~m}^{-2}$ at 70 DAP in 2013 and $3.15 \mathrm{~m}^{2} \mathrm{~m}^{-2}$ at 
Table 2 Variability in leaf area index, dry above ground biomass and extinction coefficient in both irrigation seasons

\begin{tabular}{|c|c|c|c|c|c|c|}
\hline \multirow{2}{*}{$\begin{array}{l}\text { Treatment } \\
\text { label }\end{array}$} & \multicolumn{3}{|c|}{2013 season } & \multicolumn{3}{|c|}{$2013 / 2014$ season } \\
\hline & $\begin{array}{l}\text { Leaf area } \\
\text { index } \\
\left(\mathrm{m}^{2} \mathrm{~m}^{-2}\right)\end{array}$ & $\begin{array}{l}\text { Above } \\
\text { ground } \\
\text { biomass } \\
\left(\mathrm{t} \mathrm{ha}^{-1}\right)\end{array}$ & $\begin{array}{l}\text { Extinction } \\
\text { coefficient }\end{array}$ & $\begin{array}{l}\text { Leaf area } \\
\text { index } \\
\left(\mathrm{m}^{2} \mathrm{~m}^{-2}\right)\end{array}$ & $\begin{array}{l}\text { Above } \\
\text { ground bio- } \\
\text { mass at } 84 \\
\text { DAP }\left(\mathrm{t} \mathrm{ha}^{-1}\right)\end{array}$ & $\begin{array}{l}\text { Extinction } \\
\text { coefficient }\end{array}$ \\
\hline 1. $T_{1111}$ & $7.10^{\mathrm{a}}$ & $3.42^{\mathrm{a}}$ & $0.52^{\mathrm{a}}$ & $3.44^{\mathrm{a}}$ & $2.19^{\mathrm{a}}$ & $0.42^{\mathrm{a}}$ \\
\hline 2. $T_{0111}$ & $4.79^{b}$ & $3.16^{\mathrm{a}}$ & $0.53^{\mathrm{a}}$ & $2.36^{c}$ & $1.48^{\mathrm{a}}$ & $0.40^{\mathrm{b}}$ \\
\hline 3. $T_{1011}$ & $4.17^{b c}$ & $2.67^{\mathrm{abc}}$ & $0.50^{\mathrm{b}}$ & $2.98^{\mathrm{abc}}$ & $1.35^{\mathrm{a}}$ & $0.42^{\mathrm{a}}$ \\
\hline 4. $T_{1101}$ & $3.61^{c}$ & $1.89^{c}$ & $0.49^{b}$ & $3.15^{\mathrm{ab}}$ & $1.86^{\mathrm{a}}$ & $0.42^{\mathrm{a}}$ \\
\hline 5. $T_{1110}$ & $4.53^{b}$ & $2.35^{b c}$ & $0.49^{b}$ & $2.68^{b c}$ & $1.58^{\mathrm{a}}$ & $0.39^{b}$ \\
\hline
\end{tabular}

Means of the LAls, dry aboveground biomass and extinction coefficient with the same letter are not significantly different at $5 \%(p>0.05)$ level based on Duncan multiple comparisons of means. The LAls reported were taken 86 and 49 DAP in 2013 and 2013/2014 seasons respectively while the dry aboveground biomass were taken 84 DAP in the two seasons. The extinction coefficients reported are means from replicates

49 DAP in the 2013/2014 irrigation season. There was a decline in the LAIs immediately after the maximum LAIs were reached in the two seasons in all the treatments. The decline in LAIs was faster when irrigation was skipped every other week during seed filling than in any other irrigation treatment. This was due to long period of water stress which initiated early senescence and aging of the leaves during the mid season (Blum 1996). The treatment where irrigation was skipped every other week during seed filling was able to recover after the skipping of irrigation because the LAI only reduced by $50 \%$ compared with the fully irrigated plot. This shows that the crop is tolerant to long periods of water stress.

The patterns of fIPARs in the two seasons are similar (Fig. 2). The fully irrigated treatment attained the peak fIPAR in both seasons while water stress at flowering, pod initiation and seed filling reduced the fIPAR. The effects of the water stress on fIPAR were higher in the 2013/2014 irrigation season for all the treatments where irrigation was stopped every other week. The difference in the fIPAR between the treatment where irrigation was skipped during flowering and FI was small compared with the treatment where irrigation was skipped during seed filling, which means that skipping of irrigation every other week during the late reproductive stage affects foliage formation more than in the early reproductive stage. The fIPAR was positively and significantly $(\mathrm{p}<0.0001)$ correlated with LAI using an exponential model $\left(0.98 \leq \mathrm{r}^{2} \leq 0.99 ; 0.027 \leq \mathrm{SEE} \leq 0.047\right)$ in 2013 and $\left(0.96 \leq \mathrm{r}^{2} \leq 0.99 ; 0.026 \leq \mathrm{SEE} \leq 0.057\right)$ in $2013 / 2014$ seasons across water regimes (Fig. 3). This indicates that LAIs accounted for more than $96 \%$ of the variability in the fIPARs. The TIPARs were higher in the first season ranging from $333 \mathrm{MJ} \mathrm{m}^{-2}$ when irrigation was skipped during pod initiation to $392 \mathrm{MJ} \mathrm{m}^{-2}$ for the fully irrigated plan. The TIPAR for the FI plan was higher than those of $\mathrm{T}_{0111}, \mathrm{~T}_{1110}, \mathrm{~T}_{1101}$ and $\mathrm{T}_{1011}$ by $11.2,12.5,14.5$ and $15.1 \%$ respectively. However, it was lower in the second season, from $233 \mathrm{MJ} \mathrm{m}^{-2}$ for water stress during seed filling to $276 \mathrm{MJ} \mathrm{m}^{-2}$ for full irrigation (Fig. 4).

\section{Leaf extinction coefficient}

Pooled over the years, average seasonal $\lambda$ ranged from 0.45 when irrigation was skipped during maturity to 0.47 when it was skipped during flowering, pod initiation and seed filling (Fig. 5). The $\lambda$ is generally lower in the first season and in the treatments that were 

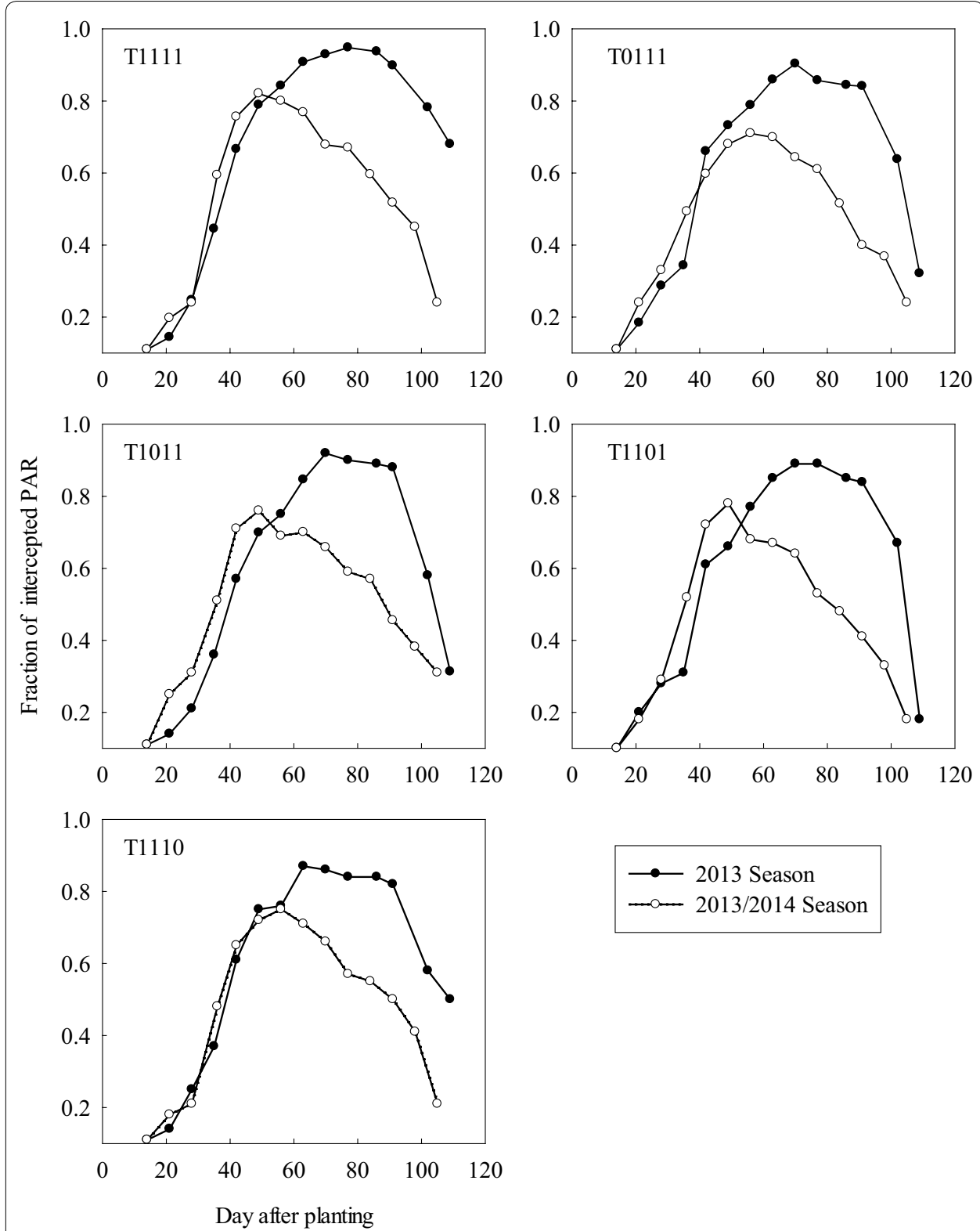

Fig. 2 Changes in the fraction of intercepted PAR for soybeans under full and deficit irrigation in both seasons

subjected to water stress compared to FI (Table 2). Lower $\lambda$ for the treatments where the crop was not fully irrigated indicates that there were more vertical leaves which ensure even distribution of light in the canopy. The average $\lambda$ in the 2013/2014 season was significantly $(\mathrm{p}<0.05)$ higher than that of 2013.

\section{DAB and fIPAR}

There was seasonal variability in the effects of water stress on DAB (Fig. 6). The effect of the water stress was higher in the second season than in the first season. DI during pod initiation reduced DAB significantly $(\mathrm{p}<0.05)$ compared with that of FI (Table 2). Similarly, water stress at seed filling and commencement of maturity reduced DAB by 


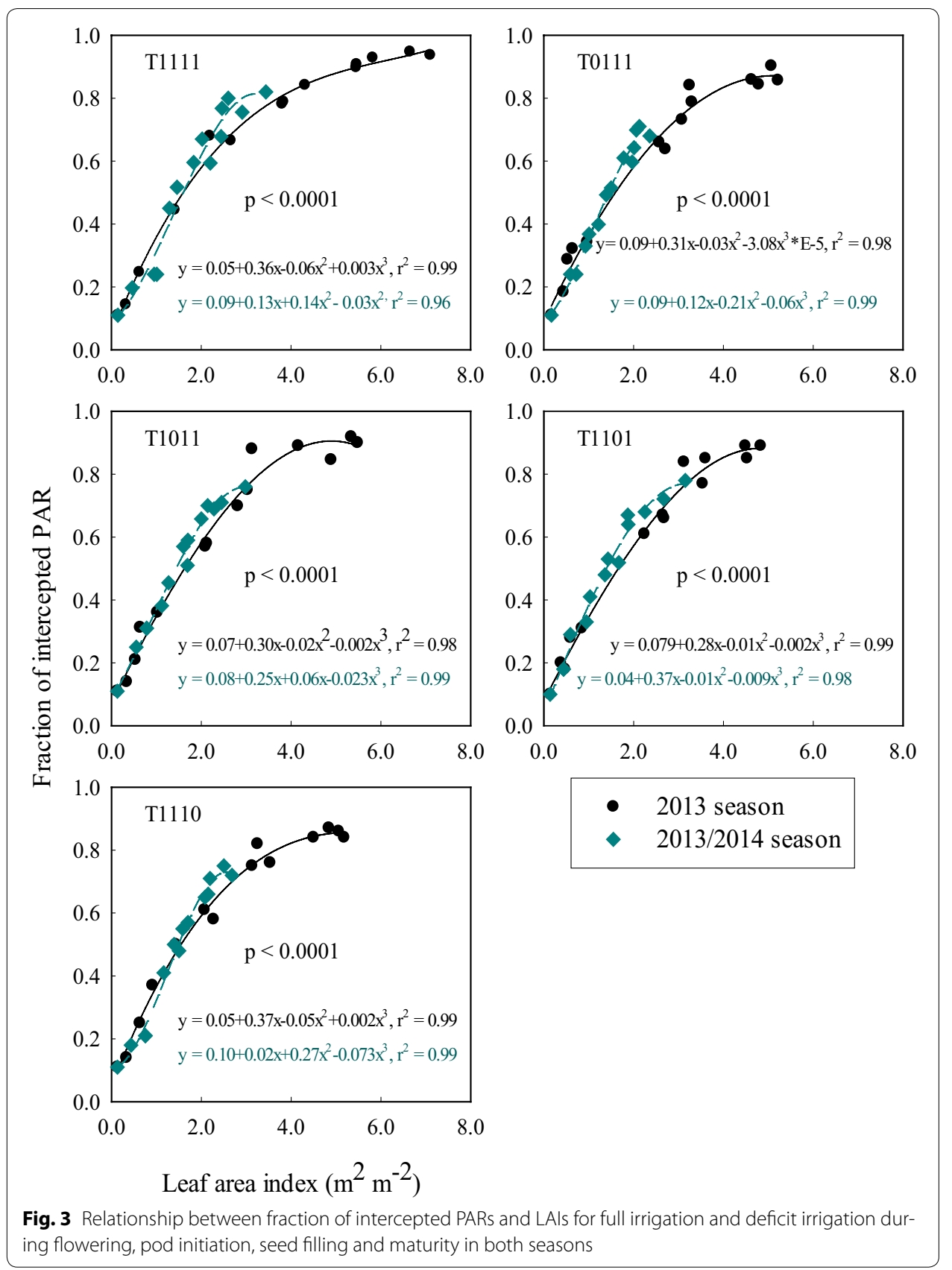

a seasonal average of $15 \%(\mathrm{p}>0.05)$ and $28 \%(\mathrm{p}<0.05)$ respectively. DAB reached the peak during seed filling in the 2013/2014 irrigation season unlike in the 2013 irrigation season when it reached the peak at maturity. DAB at 109 DAP when irrigation was skipped during pod initiation and maturity reduced by 20 and $34.4 \%$ respectively in 2013 season. However, in 2013/2014 irrigation season, the percentage reduction in DAB when irrigation was skipped ranged from 16.6 to $19.8 \%$. Higher LAIs for full irrigated treatment resulted into formation of higher canopy and interception of the incident SR by the crop and produced higher DAB. 


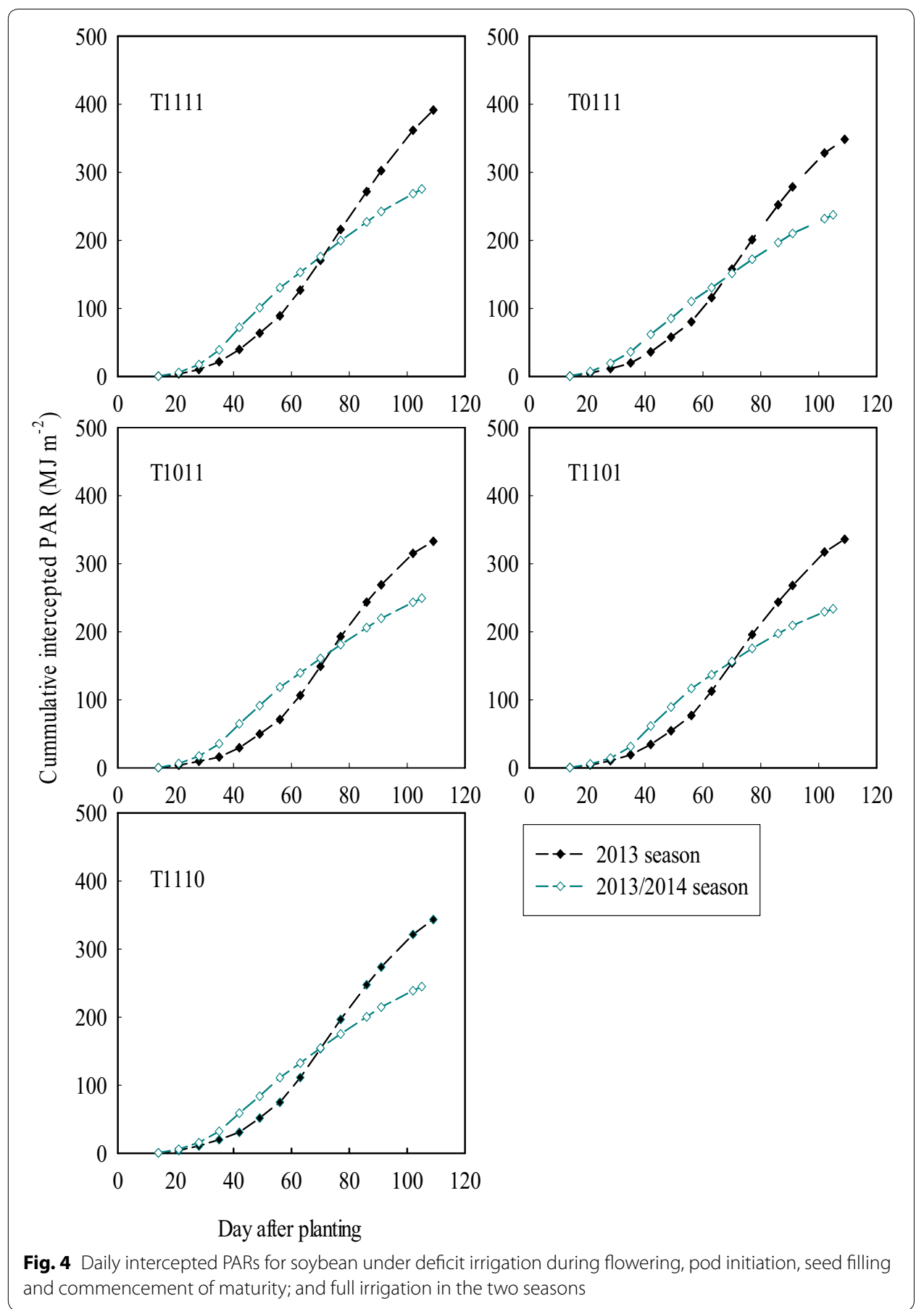

There was variability in the IPAR during the growing seasons (Fig. 4). The TIPAR in the 2013 season was higher than that of 2013/2014 season for FI treatment and the treatment where irrigation was stopped during flowering, pod initiation, seed filling and maturity. In the first season, daily IPAR was lower from the initial stage to the mid reproductive stage compared with the 2013/2014 season. FI produced the peak TIPAR in both seasons while skipping of irrigation during pod initiation and seed filling had the minimum TIPAR in both seasons. The TIPAR when irrigation was skipped during 


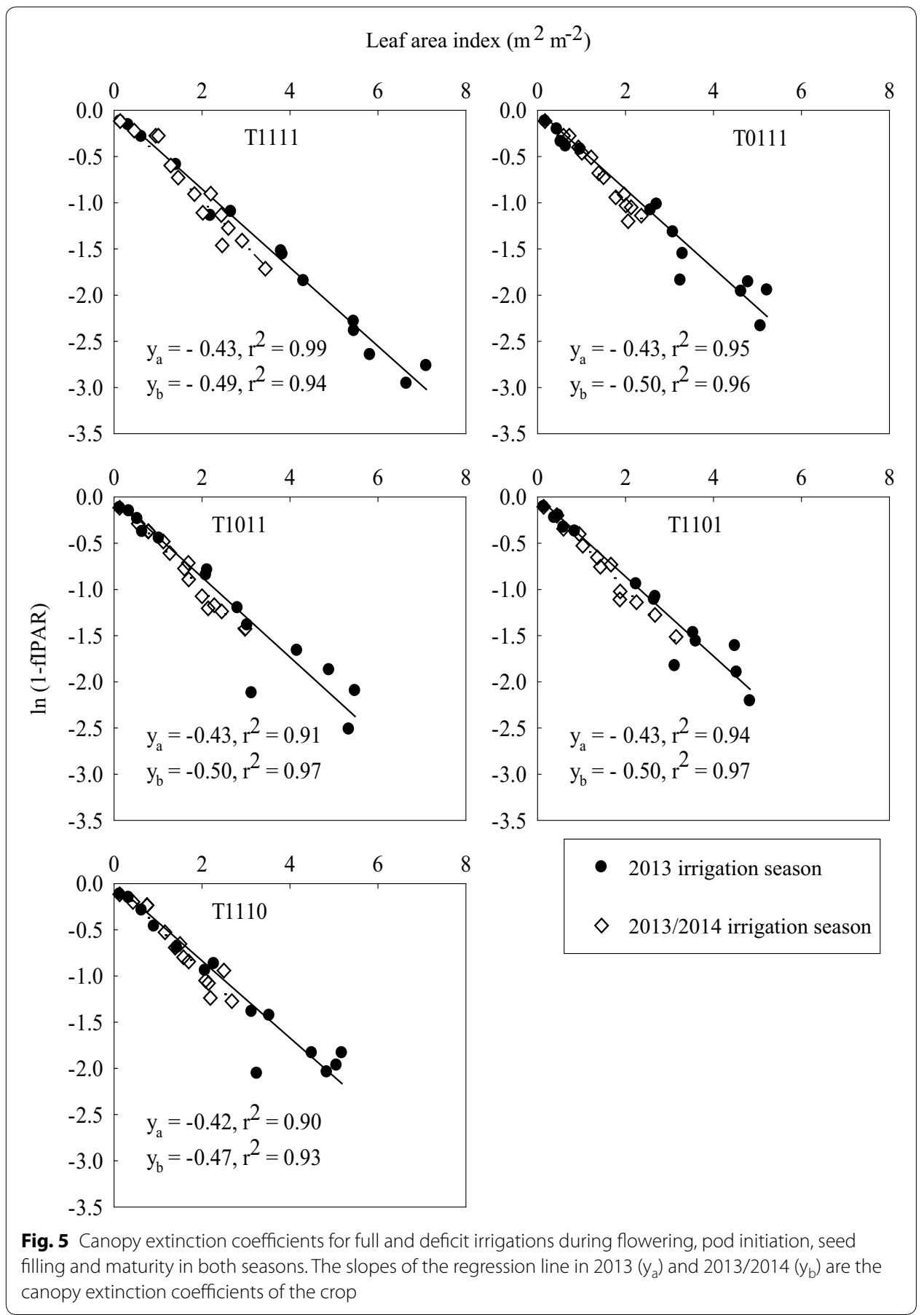

pod initiation was slightly lower than when it was skipped during seed filling in the first season.

RUE

There was strong, positive and significant correlation $(\mathrm{p}<0.0001)$ between DAB and daily IPAR in the two seasons $\left(0.92 \leq \mathrm{r}^{2} \geq 0.98\right)$ and across the water regimes (Fig. 7). $\mathrm{FI}$ and skipping of irrigation during flowering had the least and maximum RUEs $\left(\mathrm{g} \mathrm{M}^{-1}\right.$ 


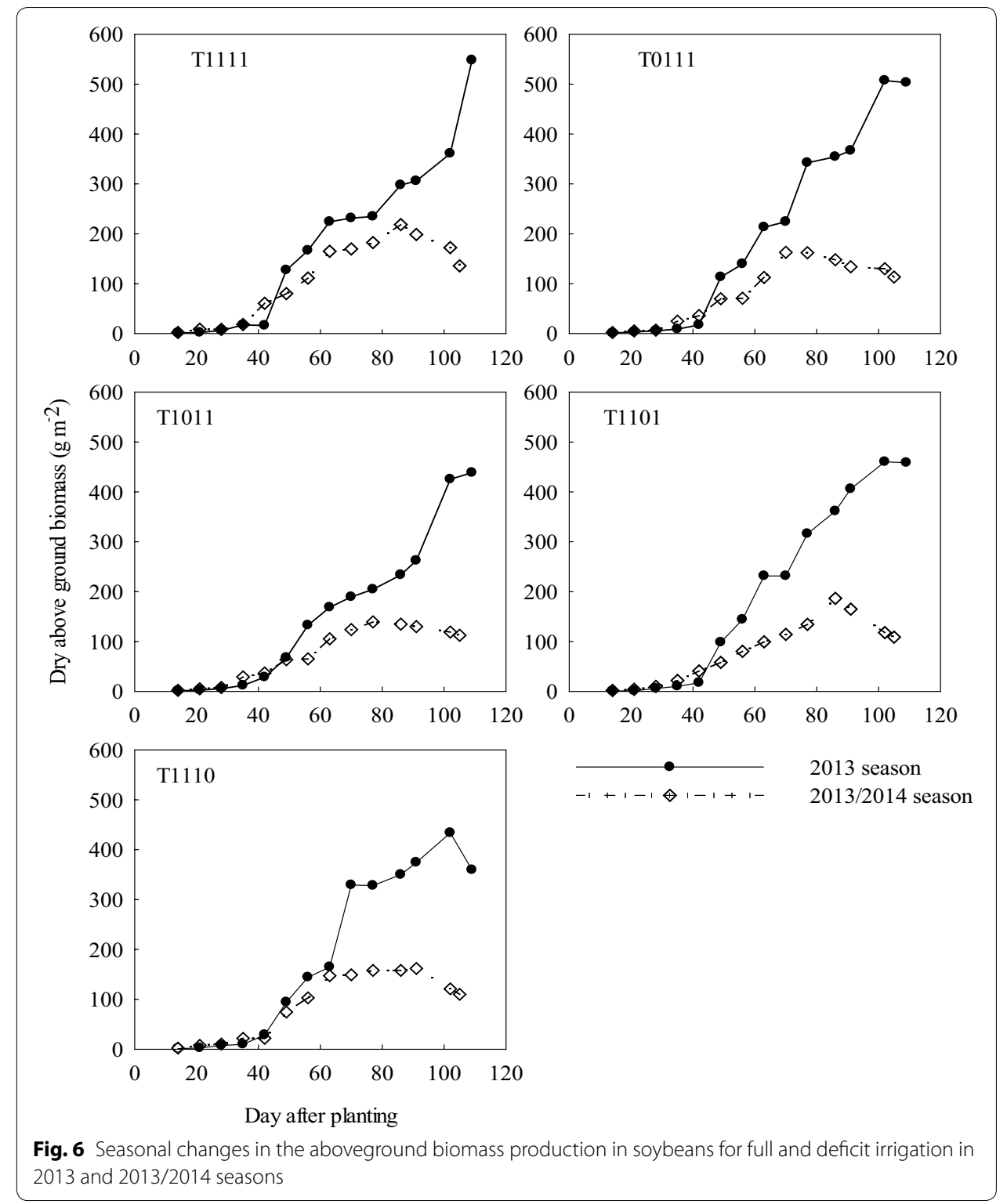

IPAR) respectively in the first season while in the second season, FI and skipping of irrigation during pod initiation had the maximum and least RUE respectively. Average seasonal RUE when irrigation was skipped during flowering was 3.8 and $7.6 \%$ higher than when it was skipped during seed filling and maturity. It was higher than when fully irrigated and irrigation was skipped during pod initiation by 10.5 and $19.7 \%$ respectively. The mean seasonal RUE in the $2013\left(1.31 \mathrm{~g} \mathrm{MJ}^{-1}\right.$ IPAR $)$ was significantly higher $(\mathrm{p}<0.001)$ than that of the $2013 / 2014\left(0.87 \mathrm{~g} \mathrm{M}^{-1}\right.$ IPAR $)$.

\section{Seed yield, $\mathrm{HI}$ and TIPAR}

Seed yields and $\mathrm{HI}$ in the first season were higher than those of the second season (Table 3). Analysis of variance shows that there were significant differences in both the seed yields and HIs among the treatments. Although, the fully irrigated treatment had the highest yield, it was not significantly higher $(p>0.05)$ than the treatment when 


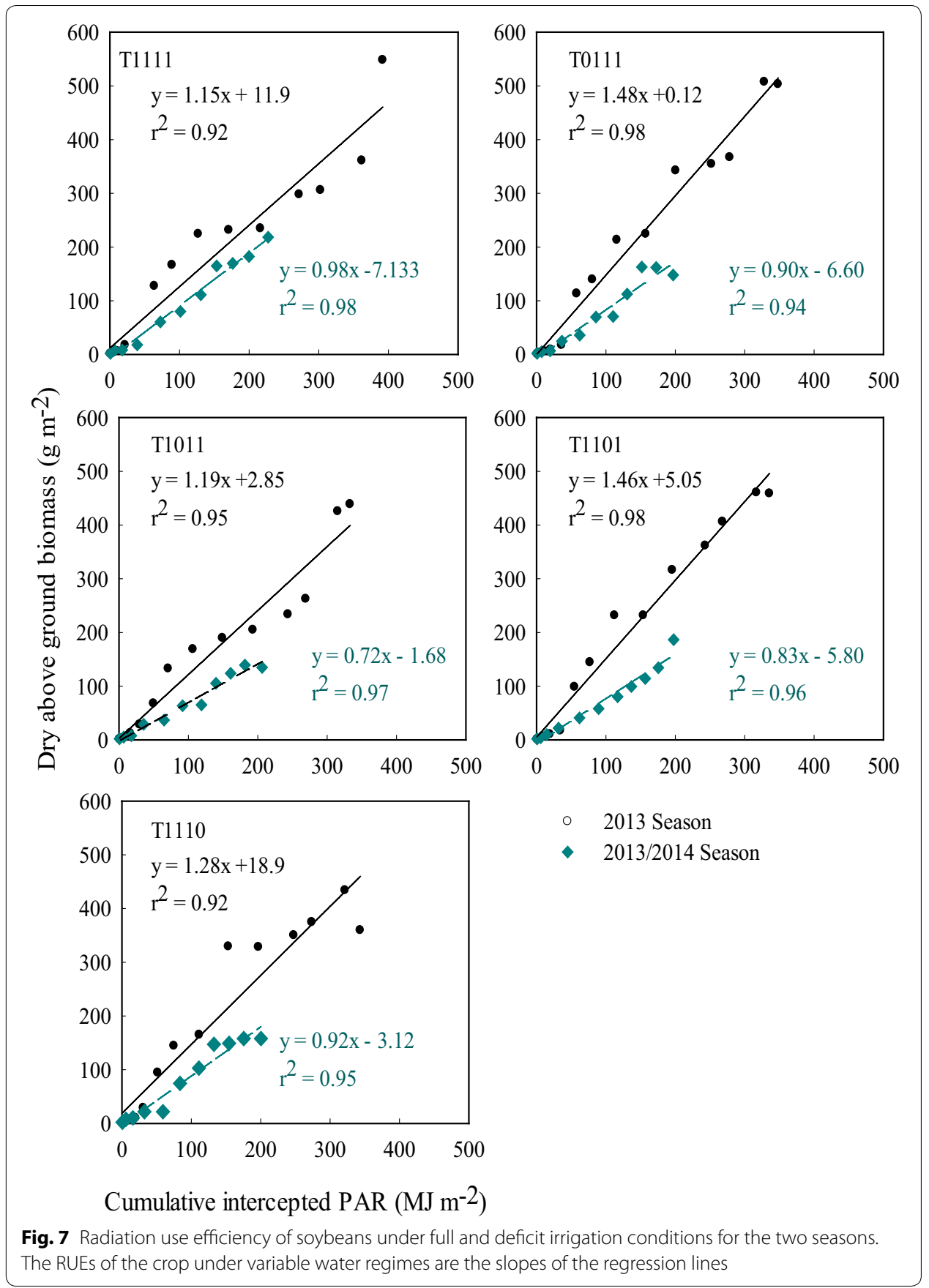

irrigation was skipped during flowering. Seed yield when irrigation was skipped during seed filling was significantly lower than the fully irrigated treatment in both seasons. Similarly, HI for skipping irrigation during seed filling was significantly lower than when irrigation was skipped during flowering and pod initiation in the first season. In the second season, water stress every other week during seed filling reduced the HI significantly compared with that of FI. Pooled over the seasons, seed yield and HIs were not significantly correlated using a polynomial model $\left(\mathrm{r}^{2}=0.65, \mathrm{p}>0.05\right)$. The TIPAR varied across the years and water regimes. Across water regimes and the years, seed yield was 
Table 3 Seasonal evapotranspiration and seed yields after the irrigation seasons

\begin{tabular}{|c|c|c|c|c|c|c|}
\hline $\begin{array}{l}\text { Treatment } \\
\text { label }\end{array}$ & $\begin{array}{l}\text { Seed yield } \\
\left(\mathrm{t} \mathrm{ha}^{-1}\right)\end{array}$ & $\begin{array}{l}\text { Irrigation } \\
\text { water }(\mathrm{mm})\end{array}$ & $\begin{array}{l}\text { Seasonal } \\
\text { water use } \\
(\mathrm{mm})\end{array}$ & $\begin{array}{l}\mathrm{WP}_{\text {seed }} \\
\left(\mathrm{kg} \mathrm{ha}^{-1}\right. \\
\left.\mathrm{mm}^{-1}\right)\end{array}$ & $\begin{array}{l}\mathrm{IWP}_{\text {seed }} \\
\left(\mathrm{kg} \mathrm{ha}^{-1}\right. \\
\left.\mathrm{mm}^{-1}\right)\end{array}$ & $\begin{array}{l}\text { Harvest } \\
\text { index (HI) (\%) }\end{array}$ \\
\hline \multicolumn{7}{|l|}{2013 season } \\
\hline 1. $T_{1111}$ & $3.11 \pm 0.77^{\mathrm{a}}$ & 262 & $523 \pm 2.00^{\mathrm{a}}$ & 5.95 & 11.9 & $61.3 \pm 2.9^{\mathrm{abc}}$ \\
\hline 2. $T_{0111}$ & $2.82 \pm 0.29^{\mathrm{a}}$ & 202 & $463 \pm 1.57^{d}$ & 6.09 & 14.0 & $65.9 \pm 1.6^{\mathrm{a}}$ \\
\hline 3. $T_{1011}$ & $2.32 \pm 0.26^{\mathrm{ab}}$ & 219 & $480 \pm 2.00^{c}$ & 5.11 & 11.2 & $62.4 \pm 5.5^{\mathrm{ab}}$ \\
\hline 4. $T_{1101}$ & $1.81 \pm 0.40^{\mathrm{b}}$ & 204 & $465 \pm 0.50^{d}$ & 3.89 & 8.9 & $56.0 \pm 3.0^{c}$ \\
\hline 5. $T_{1110}$ & $2.31 \pm 0.35^{\mathrm{ab}}$ & 234 & $495 \pm 1.20^{b}$ & 4.66 & 9.9 & $59.6 \pm 1.3^{b c}$ \\
\hline \multicolumn{7}{|c|}{ 2013/2014 season } \\
\hline 1. $T_{1111}$ & $1.52 \pm 0.28^{\mathrm{a}}$ & 457 & $507 \pm 2.12^{\mathrm{a}}$ & 3.00 & 3.32 & $63.9 \pm 7.8^{\mathrm{a}}$ \\
\hline 2. $T_{0111}$ & $1.09 \pm 0.30^{\mathrm{ab}}$ & 431 & $481 \pm 2.12^{b}$ & 2.26 & 2.52 & $56.1 \pm 4.6^{\mathrm{ab}}$ \\
\hline 3. $T_{1011}$ & $1.24 \pm 0.29^{\mathrm{a}}$ & 404 & $454 \pm 3.54^{d}$ & 2.74 & 3.08 & $55.4 \pm 3.2^{\mathrm{ab}}$ \\
\hline 4. $T_{1101}$ & $0.70 \pm 0.03^{b}$ & 314 & $364 \pm 0.71^{e}$ & 1.93 & 2.24 & $43.2 \pm 12.5^{b}$ \\
\hline 5. $T_{1110}$ & $1.17 \pm 0.31^{\mathrm{ab}}$ & 417 & $467 \pm 1.41^{c}$ & 2.51 & 2.81 & $54.3 \pm 6.5^{\mathrm{ab}}$ \\
\hline
\end{tabular}

Values are mean \pm SD from triplicates. Means of the yields, seasonal water use with the same letter is not significantly different at $5 \%$ ( $p>0.05$ ) level based on Duncan multiple comparisons of means

significantly related to RUE $\left(\mathrm{r}^{2}=0.52, \mathrm{p}=0.02\right)$ and TIPAR $\left(\mathrm{r}^{2}=0.99, \mathrm{p}<0.0001\right)$ using polynomial and linear models respectively. This indicates that 52 and $99 \%$ of the variability in the seed yield can be explained by RUE and TIPAR respectively.

The fully irrigated treatment had the maximum TIPARs in the two seasons while skipping irrigation during pod initiation and seed filling had the minimum values in the first and second seasons respectively. When considered over the seasons and water regimes, HI was not significantly correlated with TIPAR $\left(\mathrm{r}^{2}=0.68, \mathrm{p}=0.06, \mathrm{SEE}=4.47 \%\right)$ and RUE $\left(\mathrm{r}^{2}=0.38, \mathrm{p}=0.38\right.$, SEE $\left.=6.23 \%\right)$ respectively using a polynomial models. WP was linearly and significantly correlated with TIPAR $\left(\mathrm{r}^{2}=0.90, \mathrm{p}<0.0001\right.$, SEE $=0.53 \mathrm{~kg} \mathrm{ha}^{-1} \mathrm{~mm}^{-1}$ and RUE $\left(\mathrm{r}^{2}=0.60, \mathrm{p}<0.0001, \mathrm{SEE}=1.05 \mathrm{~kg} \mathrm{ha}^{-1} \mathrm{~mm}^{-1}\right)$. For every increment of $5 \mathrm{MJ} \mathrm{m}^{-2}$ in TIPAR and $0.1 \mathrm{~g} \mathrm{MJ}^{-1}$ IPAR in RUE, WP increased by 0.13 and $0.46 \mathrm{~kg} \mathrm{ha}^{-1} \mathrm{~mm}^{-1}$ respectively.

\section{Seed yield, WP, IWP}

There was seasonal variability in the WP. It was higher in the 2013 than $2013 / 2014$. WP when irrigation was stopped during flowering was 2.3 and $36.1 \%$ higher than the fully irrigated treatment and DI during seed filling in the first season respectively. However, in 2013/2014 season, WP for the fully irrigated treatment was 24.7 and $35.7 \%$ higher than WPs of the crop when irrigation was stopped every other week during flowering and seed filling respectively. Pooled over the years and across the irrigation regimes, seed yield was significantly related to WP using a linear relation $\left(\mathrm{r}^{2}=0.98, \mathrm{p}<0.0001\right.$, SEE $=0.13 \mathrm{t} \mathrm{ha}^{-1}$ ). This means that $98 \%$ of the variability in the seed yield was due to WP and that for every increment of $0.5 \mathrm{~kg} \mathrm{ha}^{-1} \mathrm{~mm}^{-1}$ in WP, seed yield increased by $260 \mathrm{~kg} \mathrm{ha}^{-1}$. This also means that increasing the WP does not compromise the seed yield significantly except at sensitive stages of the crop such as seed filling. Skipping of irrigation during flowering produced the peak IWP in the two seasons. IWP for skipping irrigation during flowering was 15 and $36.4 \%$ higher than FI and skipping of irrigation during seed filling respectively in the first season. In the second season, the IWP for the 
fully irrigated treatment was 24.1 and $32.5 \%$ higher than when irrigation was skipped during flowering and seed filling respectively. Across the seasons and water regimes, seed yield and IWP were significantly related using linear model $\left(\mathrm{r}^{2}=0.90, \mathrm{p}<0.0001\right.$, $\left.\mathrm{SEE}=0.28 \mathrm{tha}^{-1}\right)$.

\section{Discussion}

LAIs reduced during skipping of irrigation and increased slightly after water application in the mid season under DI in both seasons. This adjustment of the canopy is a developmental plasticity, which makes the crop to recover from water stress and perform well during drought in any environment. This characteristic was reported for soybeans (Hudak and Patterson 1995; Oya et al. 2004; Manavalan et al. 2009); chickpea (Canci and Toker 2009). Decline in LAI and intercepted PAR before flowering is due to impaired canopy expansion and changes in leaf orientation. There was rapid reduction in the LAI when irrigation was skipped during seed filling that had the longest period of water stress in both seasons and led to reduction in TIPAR by 14.5 and $15.6 \%$ in the 2013 and 2013/2014 irrigation seasons respectively. This means that extended water stress during seed filling accelerated senescence. High positive correlation between LAIs and fIPAR indicates that lower TIPAR in the treatments where irrigation was stopped was due to effects of water stress on leaf area development and this is similar to the findings in literature (Lecoeur et al. 1995; Blum 1996). There is a linear relationship between DAB and daily IPAR. Reduction in DAB especially in the treatment where irrigation was skipped during seed filling is attributed to lower intercepted PAR in both seasons.

The $\lambda$ depends on canopy structure, species and planting pattern of the plant and it ranges from 0.3 to 1.5 depending on specie (Saeki 1960; Jones 1992; Zarea et al. 2005). An $\lambda$ below 1 is obtained for non-horizontal or clumped leaf arrangement and a value $>1$ occurs for horizontal or regular leaf distributions in space (Jones 1992). Water stress at different stages of growth has been found to affect the $\lambda$ (Jeuffroy and Ney 1997). In the current study, water stress did not significantly affect the seasonal $\lambda$. Relatively constant value of $\lambda$ when irrigation was skipped during flowering, pod initiation and seed filling in the seasons indicates better adjustment of canopy in response to water stress during these periods. Lower $\lambda$ at late stage in the two seasons indicates a better adjustment of leaves to water stress. Low differences in the seasonal $\lambda$ of the crop at different stages indicate that the cultivar is tolerant to water stress. It can be used as a factor for selecting grain legumes that are capable of adjusting their canopy in response to skipping of irrigation during reproductive stage (Tesfaye et al. 2006). The $\lambda$ in this study is similar to 0.50, 0.59, 0.58 and 0.60 (non-linear regression) for soybean, Phasey bean, sesbania and vigna respectively (Pengelly et al. 1999); 0.80 (Daughtry et al. 1992); 0.53-0.99 (Flenet et al. 1996) for soybean.

The average seasonal RUEs in this study show that skipping of water application did not cause substantial reduction in the aerial dry matter accumulation. Although a cultivar of soybean was considered in this study, variability occurs in their seasonal RUEs under different water stress. Many previous research works reported decrease in RUEs and ascribed it to decline in canopy photosynthetic capacity as a consequence of senescence due to water stress (Kiniry et al. 1989; Jefferies and Mackerron 1989; Li et al. 2008; Bat-Oyun et al. 2011) or nutrient deficiency (Uhart and Andrade 1995). This was not the 
case in the first season in this study because we observed an increase in seasonal RUE even under water stress compared with FI. However, the effect of water stress was more pronounced in the second season because there was progressive reduction in the RUEs. When compared across the seasons, water stress during the pod initiation had the maximum effect on the average seasonal RUE of the crop because it was reduced by $19.7 \%$. The RUEs in the current study falls within the range recorded for soybeans in the literature. For instance, $0.89 \mathrm{~g} \mathrm{MJ}^{-1}$ of IPAR (Pengelly et al. 1999), $1.44 \mathrm{~g} \mathrm{MJ}^{-1}$ of IPAR (Singer et al. 2011), 1.32-2.52 $\mathrm{g} \mathrm{MJ}^{-1}$ IPAR (Sinclair and Muchow 1999).

Yield occurs by the formation of a sink and its filling by the source. Water stress affects seed yield by reducing sink and source and depending on when it occurs and the extent of stress with respect to plant phenology (Blum 1996). Significant reduction in the seed yield in this study was due to skipping of water application, especially during seed filling. Seed yield in soybeans and some other crops depends on soil fertility and water, but significant correlation between seed yield and RUE and TIPAR in the current study clearly indicates that RUE and TIPAR are key factors for yield formation in soybeans. Therefore, in order to maximize TIPAR and RUE by high canopy, regular application of water during seed filling is essential. High correlation between seed yield and WP means that the crop is tolerant to water stress and that seed yield may not be compromised by skipping water supply for at most a week during flowering and not more than 21 days during pod initiation.

Low HIs for treatment where irrigation was skipped during seed filling in the 2013/2014 season indicate that there was poor aerial biomass accumulation that can be transferred to the reproductive organ. Dropping of flowers especially when irrigation was skipped during flowering resulted into a lower number of sinks (Blum 1996). Lack of significant differences between HIs for full and DI in the 2013 season means that the crop was able to remobilize dry matter accumulated shortly before water stress to the reproductive organ before senescence (Turner et al. 2005; Tesfaye et al. 2006). The differences in HIs under full and DI therefore indicate that water stress at different stages affects the rate at which biomass is partitioned into seed in soybeans.

\section{Conclusion}

In this study, it is hereby concluded that the fIPAR is strongly and significantly correlated with green LAI under full and DI conditions. Hence, a cultivar that intercepts a high proportion of PAR is suitable in Sub-humid environments. Relatively stable $\lambda s$ even under severe water stress for long and short periods of time show that the cultivar is efficient in canopy modification and adjustment to neutralize the effects of water stress. Seed yield is strongly correlated with TIPAR and RUE. This indicates that TIPAR and RUE are key components of seed yield in soybeans. Under full and DI during reproductive stages, RUE of a cultivar of soybeans was analyzed. There was variability in the seasonal RUE. The RUE in this study fall within those reported in literature showing the conservative nature of the RUE of the crop. The least average seasonal RUE was $0.96 \mathrm{~g} \mathrm{MJ}^{-1}$ of IPAR when irrigation was skipped every other week during the pod initiation. Variability in the RUE of the crop under water stress can be used during breeding programs to develop new cultivars that are more adapted to a Sub-humid environment. Variability in the HI shows that the rate of biomass translocation into the seed is affected by water stress and 
varies with the time and severity of the water stress. Due to scarcity of information on the response of soybeans to TIPAR and water stress in the study area, the information generated in the current study will aid the development of radiation based growth models which will be more suitable for Sub-humid environments in the tropics under full and DI conditions.

\section{Abbreviations}

DI: deficit irrigation; RUE: radiation use efficiency; HI: harvest index; WP: crop water productivity; $\lambda$ : extinction coefficient: IPAR: intercepted photosynthetically active radiation; LA: leaf area; LAl: leaf area index; SR: solar radiation; fIPAR: fraction of intercepted photosynthetically active radiation; DOY: day of the year; DAP: days after planting; DAB: dry aboveground biomass; PAR below: PAR below canopy; PAR above: PAR above canopy; IWP: irrigation water productivity; I: seasonal irrigation water applied; ANOVA: analysis of variance; SEE: standard error of estimate; SAS: statistical package.

\section{Authors' contributions}

OBA wrote the proposal and designed the experiment, carried out the field work, analysed, interpreted the data collected from the field and wrote the manuscript. BS coordinated and did oversee the entire research activities, supervised the experimental design, corrected the proposal, and revised the manuscript. KOA revised the proposal, supervised the field work in Nigeria, and corrected the manuscript. KP revised the proposal and corrected the manuscript. All authors read and approved the final manuscript.

\section{Author details}

${ }^{1}$ Department of Agricultural and Environmental Engineering, Obafemi Awolowo University, Ile-Ife, Nigeria. ${ }^{2}$ Chairgroup, Land and Water Development, UNESCO-IHE Institute for Water Education, Delft, The Netherlands. ${ }^{3}$ Irrigation and Water Resources Management Consultant, Lalitpur, Nepal.

\section{Acknowledgements}

We would like to thank Prof. O.O. Jegede of the Department of Physics, Obafemi Awolowo University, Nigeria for sharing meteorological data with us and Mr. A. Jejelola of the Institute for Agricultural Research and Training (IAR\&T) Ibadan, Obafemi Awolowo University House Station for providing technical assistance during the fieldwork. We are sincerely grateful to the Dutch government under Netherlands Fellowship Programme (NFP) for providing the funding for this research. We would also like to thank the reviewer and editors of the journal for their constructive and objective criticisms and suggestions for improvement of the manuscript.

\section{Competing interests}

The authors declare that they have no competing interests.

Received: 3 February 2016 Accepted: 26 April 2016

Published online: 04 May 2016

\section{References}

Adeboye OB, Schultz B, Adekalu KO, Prasad K (2015) Crop water productivity and economic evaluation of drip-irrigated soybeans (Glycine max L. Merr.). Agric Food Secur 4(1):1-13

Ali MH (2010) Fundamentals of irrigation and on-farm water management, vol 1. Springer, Berlin

Allen RG, Pereira LS, Raes D, Smith M (1998) Crop Evapotranpiration: guidelines for computing crop water requirements. FAO Irrigation and Drainage Paper No. 56, Food and Agriculture Organization (FAO), Land and Water Development Division, Rome

Bat-Oyun T, Shinoda M, Tsubo M (2011) Effects of water and temperature stresses on radiation use efficiency in a semiarid grassland. J Plant Interact 7:214-224

Blum A (1996) Crop responses to drought and the interpretation of adaptation. Plant Growth Regul 20:135-148

Campbell GS, Norman JM (1998) An introduction to environmental biophysics, 2nd edn. Springer, New York

Canci H, Toker C (2009) Evaluation of yield criteria for drought and heat resistance in chickpea (Cicer arietinum L.). J Agron Crop Sci 195:47-54

Ceotto E, Castelli F (2002) Radiation-use efficiency in flue-cured tobacco (Nicotiana tabacum L.): response to nitrogen supply, climatic variability and sink limitations. Field Crops Res 74:117-130

Ceotto E, Di Candilo M, Castelli F, Badeck F-W, Rizza F, Soave C, Marletto V (2013) Comparing solar radiation interception and use efficiency for the energy crops giant reed (Arundo donax L.) and sweet sorghum (Sorghum bicolor L. Moench). Field Crops Res 149:159-166

Daughtry CST, Gallo KP, Goward SN, Prince SD, Kustas WP (1992) Spectral estimates of absorbed radiation and phytomass production in corn and soybean canopies. Remote Sens Environ 39:141-152

Farahani HJ, Izzi G, Oweis TY (2009) Parameterization and evaluation of the AquaCrop model for full and deficit irrigated cotton. Agron J 101:469-476

Flenet F, Kiniry JR, Board JE, Westgate ME, Reicosky DC (1996) Row spacing effects on light extinction coefficients of corn, sorghum, soybean, and sunflower. Agron J 88:185-190

Gifford RM, Thorne JH, Hitz WD, Giaquinta RT (1984) Crop productivity and photoassimilate partitioning. Science 225:801-808 
Green CF, Hebblethwaite PD, Ison DA (1985) A quantitative analysis of varietal and moisture status effects on the growth of Vicia faba in relation to radiation absorption. Ann Appl Biol 106:143-155

Hudak CM, Patterson RP (1995) Vegetative growth analysis of a drought-resistant soybean plant introduction. Crop Sci 35:464-471

Inman-Bamber NG (2004) Sugarcane water stress criteria for irrigation and drying off. Field Crops Res 89:107-122

Jamieson PD, Martin RJ, Francis GS, Wilson DR (1995) Drought effects on biomass production and radiation-use efficiency in barley. Field Crops Res 43:77-86

Jefferies RA, Mackerron DKL (1989) Radiation interception and growth of irrigated and droughted potato (Solanum tuberosum). Field Crops Res 22:101-112

Jeuffroy M-H, Ney B (1997) Crop physiology and productivity. Field Crops Res 53:3-16

Jones HG (1992) Plants and microclimate: a quantitative approach to environmental plant physiology, 2nd edn. Cambridge University Press, Cambridge, pp 10-46

Keller J, Bliesner RD (1990) Sprinkler and trickle irrigation. Van Noststrand Reinhold, New York, pp 39-52

Kiniry JR, Jones CA, O'toole JC, Blanchet R, Cabelguenne M, Spanel DA (1989) Radiation-use efficiency in biomass accumulation prior to grain-filling for five grain-crop species. Field Crops Res 20:51-64

Lecoeur J, Wery J, Turc O, Tardieu F (1995) Expansion of pea leaves subjected to short water deficit: cell number and cell size are sensitive to stress at different periods of leaf development. J Exp Bot 46:1093-1101

Li Q, Chen Y, Liu M, Zhou X, Yu S, Dong B (2008) Effects of irrigation and planting patterns on radiation use efficiency and yield of winter wheat in North China. Agric Water Manag 95:469-476

Li HL, Luo Y, Ma JH (2011) Radiation-use efficiency and the harvest index of winter wheat at different nitrogen levels and their relationships to canopy spectral reflectance. Crop Pasture Sci 62:208-217

Lovelli S, Perniola M, Ferrara A, Di Tommaso T (2007) Yield response factor to water (Ky) and water use efficiency of Carthamus tinctorius L. and Solanum melongena L. Agric Water Manag 92:73-80

Manavalan LP, Guttikonda SK, Tran L-SP, Nguyen HT (2009) Physiological and molecular approaches to improve drought resistance in Soybean. Plant Cell Physiol 50:1260-1276

Michael AM (2008) Irrigation, theory and practice. Vikas Publishing House PVT Ltd, New Delhi

Monteith JL (1977) Climate and the efficiency of crop production in Britain. Philos Trans R Soc Lond 281:277-294

Muchow RC (1985) An analysis of the effects of water deficits on grain legumes grown in a semi-arid tropical environment in terms of radiation interception and its efficiency of use. Field Crops Res 11:309-323

Narayanan S, Aiken RM, Vara Prasad PV, Xin Z, Yu J (2013) Water and radiation use efficiencies in sorghum. Agron J 105:649-656

Oya T, Nepomuceno AL, Neumaier N, Farias JRB, Tobita S, Ito O (2004) Drought tolerance characteristics of Brazilian soybean cultivars-evaluation and characterization of drought tolerance of various Brazilian Soybean cultivars in the field. Plant Prod Sci 7:129-137

Pengelly BC, Blamey FPC, Muchow RC (1999) Radiation interception and the accumulation of biomass and nitrogen by soybean and three tropical annual forage legumes. Field Crops Res 63:99-112

Plenet D, Mollier A, Pellerin S (2000) Growth analysis of maize field crops under phosphorus deficiency. II. Radiation-use efficiency, biomass accumulation and yield components. Plant Soil 224:259-272

Purcell LC, Ball RA, Reaper JD, Vories ED (2002) Radiation use efficiency and biomass production in soybean at different plant population densities. Crop Sci 42:172-177

Rinaldi M, Garofalo P (2011) Radiation-use efficiency of irrigated biomass sorghum in a Mediterranean environment. Crop Past Sci 62:830-839

Ritchie JT, Godwin DC, Otter-Nacke S (1985) CERES-wheat: a simulation model of wheat growth and development. Texas A. \& M University Press, College Station

Saeki T (1960) Interrelationships between leaf amount, light distribution and total photosynthesis in a plant community. Bot Mag Tokyo 73:55-63

Saha S, Sehgal VK, Nagarajan S, Pal M (2012) Impact of elevated atmospheric $\mathrm{CO}_{2}$ on radiation utilization and related plant biophysical properties in pigeon pea (Cajanus cajan L.). Agric For Meteorol 158-159:63-70

Sinclair TR, Muchow RC (1999) Radiation use efficiency. Adv Agron 65:215-265

Singer JW, Meek DW, Sauer TJ, Prueger JH, Hatfield JL (2011) Variability of light interception and radiation use efficiency in maize and soybean. Field Crops Res 121:147-152

Singh P, Rama YV (1989) Influence of water deficit on transpiration and radiation use efficiency of chickpea (Cicer arietinum L). Agric For Meterol 48(3-4):317-330

Sivakumar MVK, Virmani SM (1984) Crop productivity in relation to interception of photosynthetically active radiation. Agric For Meteorol 31:131-141

Stockle CO, Kemanian AR (2009) Crop radiation capture and use efficiency: a framework for crop growth analysis. In: Sadras V, Calderini D (eds) Crop physiology. Academic Press, San Diego, pp 145-170

Stone PJ, Wilson DR, Reid JB, Gillespie RN (2001) Water deficit effects on sweet corn. I. Water use, radiation use efficiency, growth, and yield. Aust J Agric Res 52:103-113

Tesfaye K, Walker S, Tsubo M (2006) Radiation interception and radiation use efficiency of three grain legumes under water deficit conditions in a semi-arid environment. Eur J Agron 25:60-70

Turner NC, Wright GC, Siddique KHM (2001) Adaptation of grain legumes (pulses) to water-limited environments. Adv Agron 71:193-231

Turner NC, Davies SL, Plummer JA, Siddique KHM (2005) Seed filling in grain legumes under water deficits, with emphasis on chickpeas. In: Donald LS (ed) Advances in agronomy, vol 87. Academic Press, New York, pp 211-250

Uhart SA, Andrade FH (1995) Nitrogen deficiency in maize: I. Effects on crop growth, development, dry matter partitioning, and kernel set. Crop Sci 35:1376-1383

Zarea MJ, Ghalavand A, Daneshian J (2005) Effect of planting patterns of sunflower on yield and extinction coefficient. Agron For Sustain Dev 25:513-518 
Zhang H, Owie T (1999) Water-yield relations and optima irrigation scheduling of wheat in the Mediterranean region. Agric Water Manag 38:195-211

Zhang J, Sun J, Duan A, Wang J, Shen X, Liu X (2007) Effects of different planting patterns on water use and yield performance of winter wheat in the Huang-Huai-Hai plain of China. Agric Water Manag 92:41-47

Submit your manuscript to a SpringerOpen ${ }^{\circ}$ journal and benefit from:

- Convenient online submission

- Rigorous peer review

- Immediate publication on acceptance

- Open access: articles freely available online

- High visibility within the field

- Retaining the copyright to your article

Submit your next manuscript at $\boldsymbol{\nabla}$ springeropen.com 